\title{
1 Solar-driven reforming of solid waste for a sustainable future
}

2 Taylor Uekert, Christian M. Pichler, Teresa Schubert and Erwin Reisner*

3 Department of Chemistry, University of Cambridge, Lensfield Road, Cambridge CB2 1EW, UK

$4 \quad{ }^{*}$ Corresponding author: reisner@ch.cam.ac.uk

5

6

7 Preface. Approximately $70 \%$ of global municipal solid waste is lost to landfills or the 8 environment each year, an emblem of our increasingly unsustainable economic system in 9 which materials and energy are produced, used and promptly discarded. Photoreforming is a 10 sunlight-driven technology that can help disrupt this linear model by simultaneously reclaiming 11 the value in waste and contributing to renewable hydrogen production. This Review examines

12 the advantages and challenges of photoreforming of real waste streams. By reviewing 13 literature on photoreforming and conducting basic techno-economic and life cycle 14 assessments, we identify key pathways for enhancing the impact of photoreforming for a 15 carbon-neutral future. 
Today's industrialised economies feature a linear "take-make-waste" model of resource extraction, consumption and disposal. ${ }^{1}$ Although this linear system has financial incentives, our increasingly urgent need to preserve finite resources and minimise greenhouse gas emissions will require a rapid transformation of the production and use of materials and energy. For example, the energy sector (electricity, fuel, heat and transportation) accounts for $55 \%$ of anthropogenic greenhouse gas emissions. ${ }^{2}$ Renewables (solar, wind, hydro, and bioenergy) play an increasing role in electricity generation, but their intermittency and inability to produce fuel or heat keeps their contribution to global energy production below $10 \%{ }^{3}$ Hydrogen $\left(\mathrm{H}_{2}\right)$ could bridge this gap by serving as an energy carrier. $\mathrm{H}_{2}$ is light, storable and has a high specific energy density, making it ideal for applications ranging from emissionsfree fuel and heating, to industrial synthesis of fertilisers and other chemicals. ${ }^{4}$ However, $96 \%$ of $\mathrm{H}_{2}$ ( $\sim 70$ million tonnes per year) is currently produced by steam reforming of fossil fuels, resulting in 830 million tonnes of $\mathrm{CO}_{2}$ emissions per year. ${ }^{4}$ Renewable production methods are thus necessary before $\mathrm{H}_{2}$ can contribute to a sustainable energy system. goods production and agriculture. ${ }^{2}$ Waste is one contributor to these emissions, with an estimated 21 billion tonnes of material lost during industrial processes ${ }^{1}$ and an additional 2 billion tonnes of municipal waste generated by consumers each year. ${ }^{5}$ This issue is compounded by the direct disposal of $60-80 \%$ of all waste without recycling, composting or approach for addressing contemporary waste and energy challenges. This simple process employs a photocatalyst to absorb the energy in sunlight, enabling the breakdown of waste and water into small organic molecules and $\mathrm{H}_{2}$ gas. First reported in the 1980 's,${ }^{6-8}$ the majority of PR research has since relied on "model waste" substrates such as ethanol, glycerol or 
process complexity, but also improves its economics and sustainability. Different waste streams are first analysed for their compatibility with PR. The environmental impact and techno-economic feasibility of PR are then assessed, and future research recommendations are provided. By exploring the current advantages and limitations of waste PR, we aim to demonstrate that this technology can contribute to a future carbon-neutral society by simultaneously generating clean $\mathrm{H}_{2}$, mitigating waste and producing bulk chemicals for a sustainable chemical industry.

\section{Scientific principles of photoreforming}

PR is an intermediate process between solar water splitting and organic photoredox catalysis.

Water splitting is a nonspontaneous chemical reaction $\left(\Delta G^{0}=+237 \mathrm{~kJ} \mathrm{~mol}^{-1}\right.$ at $\left.25^{\circ} \mathrm{C}\right)$ involving the reduction of $\mathrm{H}_{2} \mathrm{O}$ to $\mathrm{H}_{2}$ and the oxidation of $\mathrm{H}_{2} \mathrm{O}$ to $\mathrm{O}_{2} \cdot{ }^{10}$ It is typically limited by the energetically- and kinetically-demanding $\mathrm{O}_{2}$ evolution reaction, which researchers often circumvent by introducing costly and unsustainable sacrificial electron donors. ${ }^{10,11}$ In contrast, organic photo-oxidation (a subset of photoredox catalysis) usually describes a spontaneous reaction in which $\mathrm{O}_{2}$ is reduced to radical species that subsequently oxidise organic molecules to $\mathrm{CO}_{2}, \mathrm{H}_{2} \mathrm{O}$ and/or other products. ${ }^{9}$

PR combines water reduction with organic oxidation on a semiconductor material called a photocatalyst. Under anaerobic conditions, electrons in the photocatalyst are excited by sunlight to the conduction band (CB) and reduce the protons in $\mathrm{H}_{2} \mathrm{O}$ to $\mathrm{H}_{2}$. The holes remaining in the photocatalyst valence band (VB) then oxidise an organic substrate $\left(\mathrm{C}_{x} \mathrm{H}_{y} \mathrm{O}_{z}\right)$ to $\mathrm{CO}_{2}$ or intermediate products (Fig. 1, Eq. 1). In order for PR to proceed, the incident photons must be of higher energy than the semiconductor band gap, the CB must be more negative than the reduction potential of $\mathrm{H}^{+}$to $\mathrm{H}_{2}(0 \mathrm{~V}$ vs. $\mathrm{NHE}$ at $\mathrm{pH} 0)$, and the VB must be more positive than the oxidation potential of the substrate to a given oxidation product (substrate-dependent). ${ }^{12}$ More detailed mechanistic discussions of PR can be found elsewhere.$^{9,12,13}$ 


$$
\mathrm{C}_{\mathrm{x}} \mathrm{H}_{\mathrm{y}} \mathrm{O}_{\mathrm{z}}+(2 \mathrm{x}-\mathrm{z}) \mathrm{H}_{2} \mathrm{O} \stackrel{h v}{\longrightarrow}(2 \mathrm{x}-\mathrm{z}+\mathrm{y} / 2) \mathrm{H}_{2}+\mathrm{xCO}_{2}
$$

The overall PR process is nearly energetically neutral. For example, PR of glucose (a biomass component) or ethylene glycol (a component of the plastic polyethylene terephthalate) has a standard Gibbs free energy change of $\Delta \mathrm{G}^{0}=-84.7 \mathrm{~kJ} \mathrm{~mol}{ }^{-1}$ or $\Delta \mathrm{G}^{0}=$ $+9.2 \mathrm{~kJ} \mathrm{~mol}^{-1}, 9,14$ respectively, both of which compare favourably to water splitting. PR of freely-available waste feedstocks can thus be powered by a large portion of incident sunlight, making it an attractive candidate for sustainable $\mathrm{H}_{2}$ production.

Figure 1. Diagram of the waste photoreforming process. The conduction band (CB) position of the semiconductor material (photocatalyst) is given versus the reversible hydrogen electrode (RHE).

\section{Waste as a feedstock for photoreforming}

Typical PR substrates are oxygenated organic molecules of the form $\mathrm{C}_{x} \mathrm{H}_{y} \mathrm{O}_{z}$, although nitrogen, phosphorus and sulphur can be incorporated as well. ${ }^{7}$ Studies with simple molecules have shown that PR favours substrates with low complexity, ${ }^{9,12}$ high polarity/hydrophilicity, ${ }^{15,16}$ water solubility, and functional groups that adsorb to the photocatalyst surface (e.g. hydroxyl groups). ${ }^{17}$ An ideal feedstock for PR should incorporate as many of these chemical features as possible while simultaneously being derived from waste streams that are otherwise nonreusable or non-recyclable. In this section, we examine global waste generation and determine which components can and have been used as substrates for PR.

$\underline{\text { Available waste feedstocks }}$

$70 \%$ of global municipal solid waste (MSW) is landfilled or openly dumped each year (Fig. 2a, outer ring). ${ }^{5}$ Up to eighteen times more waste is produced industrially than municipally, but due to the scarcity of data on global industrial waste composition and disposal, ${ }^{5}$ we focus primarily on MSW unless stated otherwise. While MSW management strategies vary between countries of different income levels, recycling rates still only reach a maximum of $29 \%$ in high income countries, with rates dropping below $4 \%$ in low income countries (Fig. $2 \mathrm{a}$, inner rings). ${ }^{5}$ 
This lack of adequate waste management directly impacts public health and the environment: it is predicted that global greenhouse gas emissions could be reduced by $15-20 \%$ by incorporating strategies for waste prevention and promoting recovery and recycling. ${ }^{18}$

The average global composition of MSW is dominated by food and biomass (46\%), paper and cardboard (17\%) and plastic (12\%), with glass, metal, rubber, and other waste accounting for the remaining $25 \%$ (Fig. $2 \mathrm{~b}$, outer ring).${ }^{5}$ High income countries tend towards paper and cardboard (25\%) and plastic (13\%), whereas low income countries generate more food and biomass waste $\left(57 \%\right.$, Fig. $2 \mathrm{~b}$, inner rings). ${ }^{5}$ Of these components, some biomass, food, plastic, paper and cardboard are composed of oxygenated organic molecules, making 69-77\% (region dependent) of MSW potentially usable for PR (Supplementary Table 1).

Of the waste components suitable for PR, inedible biomass is the most plentiful: nearly 4 billion tonnes of biomass residues are produced annually by agriculture and industry (Fig. 2c). ${ }^{19}$ Biomass is made of lignocellulose, a combination of cellulose fibrils cross-linked by hemicellulose and lignin polymers. ${ }^{11}$ Both cellulose and hemicellulose consist of long chains of sugars $\left(\mathrm{C}_{6} \mathrm{H}_{12} \mathrm{O}_{6}\right.$ or $\left.\mathrm{C}_{5} \mathrm{H}_{10} \mathrm{O}_{5}\right)$ that can be relatively easily photoreformed due to their polarity and high hydroxyl group content. ${ }^{9}$ Lignin, on the other hand, is a complex, hydrophobic polymer that is challenging to photoreform..$^{8,20-22}$ In addition to these raw biomass components, paper (i.e. processed biomass) also contains $10-25 \mathrm{wt} \%$ mineral fillers and pigments that cannot be photoreformed..$^{23}$ Depending on the exact type of biomass selected, the total chemical content currently accessible for PR is $55-95$ wt $\%$, although this number could increase with the ongoing development of photocatalysts capable of reforming lignin.

The chemical composition of food waste varies greatly (Fig. 2c). For example, cereals contain $70-80 \%$ carbohydrates (good substrates for PR), ${ }^{24}$ whereas meat consists primarily of proteins $(10-20 \%)$ and fats $(2-50 \%) .{ }^{25}$ Proteins are made of long chain(s) of amino acid residues and should undergo PR to a certain extent, ${ }^{7,26}$ depending on the quantity of oxidisable functional groups and the complexity of the three-dimensional protein structure. Fats are more challenging to utilise in water-based PR due to their hydrophobicity and (typically) chemically inert hydrocarbon chain. The accessible chemical content of food waste could therefore vary 
between as low as $10 \%$ for meat, fish or dairy to as high as $80 \%$ for cereals, potentially making it difficult to maintain a consistent $\mathrm{H}_{2}$ output from PR.

Finally, synthetic polymers (plastics) comprise a relatively small portion of global waste (302 million tonnes per year), ${ }^{27}$ but are of particular concern due to their non-biodegradability and accumulation in the environment. The majority of plastics are hydrocarbon chains ${ }^{27}-$ such as polyethylene $\left(\mathrm{C}_{2} \mathrm{H}_{4}\right)_{n}$ and polypropylene $\left(\mathrm{C}_{3} \mathrm{H}_{6}\right)_{n}$ - which are currently difficult to reform because of their highly stable C-C bonds. ${ }^{28}$ However, the remaining $\sim 16-17 \%{ }^{27}$ of plastics are oxygenated, polar and contain esters that can facilitate PR. ${ }^{14,29}$ Examples include polyethylene terephthalate $\left(\mathrm{C}_{10} \mathrm{H}_{8} \mathrm{O}_{4}\right)_{n}$ and polyurethane $\left(\mathrm{C}_{12} \mathrm{H}_{14} \mathrm{~N}_{2} \mathrm{O}_{4}\right)_{\mathrm{n}}$, with 32 and 16 million tonnes of waste generated annually, respectively. ${ }^{27}$ Biodegradable plastics such as polylactic acid $\left(\mathrm{C}_{3} \mathrm{H}_{4} \mathrm{O}_{2}\right)_{n}$ could also be used. If the above biomass, food and plastic components were all utilised for $\mathrm{PR}$, a theoretical maximum of 310-650 million tonnes of $\mathrm{H}_{2}$ could be produced each year (the equivalent of $\sim 6-13 \%$ of annual global energy consumption).

Figure 2. Municipal waste (a) disposal methods and (b) composition. Outer rings are world averages, second rings upper income countries, third rings middle income countries and inner rings low income countries (data from ref. [5]). (c) Composition breakdown of the global waste streams usable for photoreforming (data from ref. [19,27,30,31]). Inaccessible fractions are based on current photocatalytic performance, and will likely decrease with future developments. See Supplementary Table 1 for details.

\section{Waste pre-treatment}

Before utilisation in PR, waste must undergo sorting and pre-treatment. For example, wet density separation - in which materials are separated by weight ${ }^{32}$ - could be used to isolate biomass, food and polar plastics suitable for PR from other mixed waste components that cannot be reformed or could potentially poison the photocatalyst. The waste feedstock would next be crushed, shredded or otherwise mechanically treated to produce smaller particles. ${ }^{33}$ Chemical pre-treatment could then be employed to solubilise the sorted waste, thereby facilitating contact between the photocatalyst and substrate during PR and increasing the $\mathrm{H}_{2}$ evolution rate. Several studies have explored this concept and reported enhanced PR following waste hydrolysis and solubilisation under alkaline ${ }^{7,14,21,22,26,29}$ or acidic $^{34,35}$ conditions, 
152 after steam explosion (high-pressure saturated steam) treatment, ${ }^{36}$ in metal salt hydrate 153 solutions, ${ }^{37}$ or following treatment with enzymes capable of hydrolysing cellulose 154 (cellulases). ${ }^{35,38,39}$ Chemical pre-treatment for PR is rarely researched in detail, likely due to a historic focus on PR of simple molecules (e.g. sugars and alcohols) that do not require solubilisation. Many of the reported methods therefore have limitations, such as corrosive chemicals (acids or bases), high temperatures and pressures (steam explosion), or enzymes that may be difficult or expensive to produce in bulk. Future research would benefit from the development of milder waste pre-treatments that are compatible with PR photocatalysts.

\section{State of the art waste photoreforming}

PR with real waste was first reported in 1981, when platinised $\mathrm{TiO}_{2}$ was used to generate $\mathrm{H}_{2}$ from a range of plastic (polyethylene, polyvinyl chloride, Teflon), biomass (rice plant, grass, wood, flowers, seaweed), food (sweet potato, olive oil) and other (cockroach, excrement) waste under both neutral $\left(\mathrm{H}_{2} \mathrm{O}\right)$ and alkaline $(5 \mathrm{M} \mathrm{NaOH})$ conditions. ${ }^{7,8}$ Several oxidation intermediates such as ethanol, acetate, acetone and acetaldehyde were detected in addition to the expected final product $\mathrm{CO}_{2} \cdot{ }^{8} \mathrm{PR}$ performance is typically reported as rate of $\mathrm{H}_{2}$ production per photocatalyst mass $\left(\mu \mathrm{mol} \mathrm{gcat}^{-1} \mathrm{~h}^{-1}\right)$ and $\mathrm{H}_{2}$ yield per substrate mass $(\mu \mathrm{mol}$ $\left.\mathrm{g}_{\mathrm{sub}}{ }^{-1}\right)$, but it should be noted that these metrics are difficult to compare directly when using different photocatalysts or reaction conditions (e.g. substrate concentration, reactor volume, irradiation type). ${ }^{40}$ The majority of subsequent $\mathrm{PR}$ studies have also used $\mathrm{TiO}_{2} \mid \mathrm{Pt}$ photocatalysts to photoreform alfalfa, ${ }^{41}$ bamboo, ${ }^{39}$ corn stover, ${ }^{42}$ grass,${ }^{38,39,43}$ paper,${ }^{34}$ rice,${ }^{39,41}$ wood, ${ }^{35,37}$ swine sewage, ${ }^{44}$ and olive mill, ${ }^{45}$ brewery ${ }^{46}$ and dairy ${ }^{46}$ wastewaters (see Tables S2S6 for a literature survey). Despite the prevalence of $\mathrm{TiO}_{2}$, the efficiency and up-scalability of this photocatalyst are limited by its ultraviolet-only absorption ( $4 \%$ of the solar spectrum) and need for expensive $\mathrm{H}_{2}$ evolution co-catalysts (usually $\mathrm{Pt}$ ).

CdS has emerged as an alternative to $\mathrm{TiO}_{2}$ due to its visible-light absorption (band gap of $2.4 \mathrm{eV}, \lambda<515 \mathrm{~nm}$ ) and ability to operate without a precious metal co-catalyst. A $\mathrm{LaMnO}_{3} / \mathrm{CdS}$ catalyst was first used to photoreform sewage sludge ${ }^{36}$ and CdS quantum dots 
in aqueous alkaline solution (10 $\mathrm{M} \mathrm{KOH}$ or $\mathrm{NaOH})$ were next employed to photoreform 180 biomass, ${ }^{21}$ plastics ${ }^{29}$ and food waste ${ }^{26}$ with activities of up to $9350 \mu \mathrm{mol}_{\mathrm{H}_{2}} \mathrm{~g}_{\mathrm{cat}}{ }^{-1} \mathrm{~h}^{-1}$ (for cheese). The formation of a variety of oxidation products, typically organic acids such as formate, was also reported. ${ }^{21,26,29}$ Although this system was highly efficient, the use of toxic cadmium and large quantities of base are unlikely to be feasible on a larger scale. Carbon nitride $\left(\mathrm{CN}_{\mathrm{x}}\right)$ photocatalysts have recently been explored as a visible-light-driven (band gap of $2.7 \mathrm{eV}, \lambda<460 \mathrm{~nm}$ ), non-toxic and inexpensive alternative to CdS. Biomass PR was achieved over cyanamide-functionalised $\mathrm{CN}_{\mathrm{x}}\left({ }^{\mathrm{NCN}} \mathrm{CN}_{\mathrm{x}}\right)$ coupled with a molecular $\mathrm{Ni}$ bis(diphosphine) catalyst at $\mathrm{pH} 4.5$, with an activity of $7.6 \mu \mathrm{mol}_{\mathrm{H}_{2}} \mathrm{~g}_{\mathrm{cat}}{ }^{-1} \mathrm{~h}^{-1}$ for wood. ${ }^{22}$ This efficiency was improved by $64 \%$ when the wood was solubilised in a $\mathrm{LiBr}$ metal salt hydrate solution prior to reforming with ${ }^{\mathrm{NCN}} \mathrm{CN}_{\mathrm{x}} \mid \mathrm{Pt}^{37} \mathrm{PR}$ of plastic ${ }^{14}$ and food waste ${ }^{26}$ was also accomplished with ${ }^{\mathrm{NCN}} \mathrm{CN}_{\mathrm{x}}$ or $\mathrm{CN}_{\mathrm{x}}$ coupled with a nickel phosphide $\left(\mathrm{Ni}_{2} \mathrm{P}\right)$ co-catalyst. While alkaline conditions $(1 \mathrm{M} \mathrm{KOH})$ were necessary to solubilise plastic, ${ }^{14} \mathrm{PR}$ of food, mixed and municipal wastes proceeded at neutral $\mathrm{pH}$ following a simple heat treatment at $80{ }^{\circ} \mathrm{C} .^{26}$ The oxidation half-reaction yielded a range of substrate-dependent products, with formate, acetate

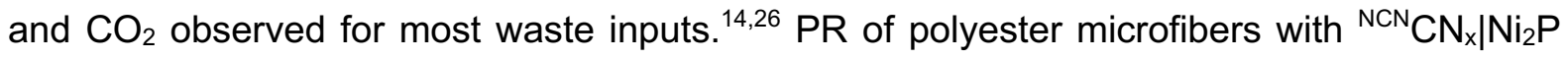
was also up-scaled from 2 to $120 \mathrm{~mL}$ with no loss in efficiency. ${ }^{14}$ See Supplementary Tables 2-8 for an exhaustive literature survey of waste PR.

The $\mathrm{H}_{2}$ evolution half-reaction of $\mathrm{PR}$ is well understood: photo-excited electrons migrate to the photocatalyst surface, transfer to a metal co-catalyst and reduce aqueous protons to $\mathrm{H}_{2}$ gas. The mechanism of the oxidation half-reaction, on the other hand, is more elusive. Substrate oxidation has been suggested to proceed by either $\mathrm{OH}^{\cdot}$ radicals ${ }^{41,43}$ or direct hole transfer. ${ }^{14,21}$ In brief, highly oxidising photo-generated holes in catalysts such as $\mathrm{TiO}_{2}$ can produce $\mathrm{OH}^{\cdot}$ radicals from $\mathrm{H}_{2} \mathrm{O}$, which subsequently diffuse to and oxidise a substrate. ${ }^{41,43}$ Alternatively, a substrate adsorbed onto the photocatalyst can be oxidised by direct hole transfer, which has been proposed for $\mathrm{CdS}$ and $\mathrm{CN}_{\mathrm{x}}{ }^{14,21}$ Oxidation has been suggested to be rate-limiting for PR due to poor interaction between the photocatalyst and substrate, the large 
number of holes required to fully oxidise certain substrates, and photocatalyst deactivation by the adsorption of harmful intermediate products. ${ }^{21,35,47}$ These latest advances in fundamental mechanistic understanding, as well as in photocatalyst and system design as described above, will enable more sustainable and scalable PR. They also highlight the need for improvements in currently under-researched areas, such as the enhancement of substratecatalyst contact and the development of more efficient, stable and inexpensive photocatalysts.

\section{Product separation}

Product extraction and storage will be required as the final step of an industrially-relevant PR system. $\mathrm{H}_{2}$ purification is traditionally accomplished by pressure swing adsorption, cryogenic distillation or membrane separation, ${ }^{48}$ although low-cost alternatives such as twin-reactors (membrane incorporated into a photoreactor) are also being developed. ${ }^{49,50}$ This step is expected to be relatively straightforward, as $\mathrm{H}_{2}$ produced by PR would only need to be separated from the carrier gas $\mathrm{N}_{2}$ and, in some cases, the oxidation product $\mathrm{CO}_{2}$. In contrast, the extraction of dissolved organic products could prove challenging as PR often yields a mixture of different oxidation intermediates. Potential extraction methods could include distillation, solvent-mediated phase separation, membrane separation, adsorption processes, or a combination thereof, but these strategies become more energetically demanding when products are mixed, at low concentrations and/or miscible with $\mathrm{H}_{2} \mathrm{O},{ }^{51}$ all characteristics of current PR processes. One strategy could be the design of selective oxidation co-catalysts capable of producing higher value molecules such as arabinose $\left(£ 17 \mathrm{~kg}^{-1}\right)$ or resorcinol (£14 $\mathrm{kg}^{-1}$ ) rather than the inexpensive acids currently formed (e.g. formate at $£ 0.50 \mathrm{~kg}^{-1}$, Supplementary Table 9); this exciting field of research requires further development.

\section{Feasibility of photoreforming}

Many benefits of PR have been reported: use of renewable solar energy, simplicity, and multiple profit streams from waste use and production of $\mathrm{H}_{2} \cdot{ }^{9,11,26}$ However, there have been 
232 only limited attempts to quantify these benefits in techno-economic and life cycle analyses. ${ }^{26}$

233 In this section, we assess the feasibility of up-scaled waste PR in comparison to other waste-

234 to-fuel technologies.

235 Economic and environmental analyses

236 A PR pilot plant capable of treating $100-300 \mathrm{~kg}$ of MSW per day was modelled and used to 237 estimate the $\mathrm{H}_{2}$ production cost $\left(£ \mathrm{~kg}_{\mathrm{H}_{2}}{ }^{-1}\right)$, carbon footprint $\left(\mathrm{gcO}_{2} \mathrm{MJ}_{\mathrm{H}_{2}}{ }^{-1}\right)$ and energy returned 238 on invested (EROI), all established metrics for determining the economic and environmental 239 feasibility of a process (Fig. 3a). Based on reported ratios, ${ }^{14,26}$ processing this quantity of waste 240 requires $4000 \mathrm{~L}$ of $\mathrm{H}_{2} \mathrm{O}, 12 \mathrm{~kg}$ of photocatalyst and $400 \mathrm{~m}^{2}$ of irradiation area assuming a reactor depth of $1 \mathrm{~cm}$ (a low reactor depth-to-area ratio is typical for sunlight-driven processes ${ }^{52,53}$ ). The waste is pre-treated overnight at $40-80{ }^{\circ} \mathrm{C}$, purged with $\mathrm{N}_{2}$ and then pumped through the flat panel photoreactors. The produced $\mathrm{H}_{2}$ is collected, compressed and stored, while the used solution is sent to water treatment or waste disposal. Plant capital, construction, operation and consumables are included, but the transportation of consumables (MSW, water, $\mathrm{N}_{2}$, etc.) and $\mathrm{H}_{2}$, as well as "negative" emissions from avoiding the landfilling of waste, are not considered (Supplementary Table 10, Supplementary Figure 1, Supplementary Methods). Calculations are based on $\mathrm{PR}$ with $\mathrm{CN}_{\times} \mid \mathrm{Ni}_{2} \mathrm{P}$ in $\mathrm{H}_{2} \mathrm{O}$; $\mathrm{PR}$ under alkaline conditions is only explored in cases labelled "NaOH reuse." $£ 11.80 \mathrm{~kg}_{\mathrm{H}_{2}}{ }^{-1}, 81.0 \mathrm{~g}_{\mathrm{CO}_{2}} \mathrm{MJ}_{\mathrm{H}_{2}}{ }^{-1}$ and EROI of 0.98 (black vertical lines in Fig. 3b, also see Supplementary Tables 11-13). The cost is high in comparison to $\mathrm{H}_{2}$ sale targets ${ }^{54}$ of $£ 3-5 \mathrm{~kg}^{-1}$ and predictions for $\mathrm{H}_{2}$ produced by photocatalytic $\left(£ 1-3 \mathrm{~kg}^{-1}\right)^{55}$ and photoelectrochemical $\left(£ 8-9 \mathrm{~kg}^{-1}\right)^{55,56}$ water splitting, although these calculations are for plants $500-2000$ times larger than our PR model so direct comparisons are difficult. A rough estimate with the 0.6 scaling rule $^{57}$ indicates that the PR plant would need to be at least thirty times larger $\left(12,000 \mathrm{~m}^{2}\right)$ in order to reach $£ 3 \mathrm{~kg}_{\mathrm{H}_{2}}{ }^{-1}$ under "base case" conditions. The EROI of "base case" PR is also 
lower than the breakeven point of one. However, both cost and EROI are expected to improve with further scaling as capital and operational expenses tend to be high for pilot plants. ${ }^{57}$ Future government initiatives for green $\mathrm{H}_{2}$ could influence economics as well. The carbon footprint of PR is already promising: "base case" PR emits $20 \%$ fewer greenhouse gases than $\mathrm{H}_{2}$ produced by steam methane reforming (100 $\mathrm{gcO}_{2} \mathrm{MJ}_{\mathrm{H}_{2}}{ }^{-1}$ without carbon capture) ${ }^{58}$ and $40 \%$ fewer (168 $\mathrm{g} \mathrm{co}_{2} \mathrm{~kg}_{\text {waste }}{ }^{-1}$ with credits for energy production) than waste disposal by landfill $\left(290 \mathrm{gcO}_{2} \mathrm{~kg}_{\text {waste }}{ }^{-1}\right) .^{59}$

The change in total $\mathrm{H}_{2}$ production cost, carbon footprint and EROI of the pilot PR plant were next explored by varying individual parameters between low and high estimates (Fig. 3b, see Supplementary Table 11 for details). The parameters with the widest bars in Fig. $3 b-$ photocatalyst reuse, photocatalyst efficiency, sunlight intensity, waste concentration and daylight hours - result in the most significant changes in cost, footprint and EROI, and will therefore have the highest impact on PR feasibility. A catalyst lifetime of at least one year is essential, especially if a more expensive material $\left(\mathrm{TiO}_{2} \mid \mathrm{Pt}\right.$, open circles) is used. If a new photocatalyst supply were used for each $24 \mathrm{~h}$ PR cycle, the material would dominate the cost, carbon footprint and EROI of plant operation unless it were significantly less expensive $(<£ 10$ $\left.\mathrm{kg}^{-1}\right)$ and more environmentally-friendly $\left(<10 \mathrm{~kg}_{\mathrm{CO}_{2}} \mathrm{~kg}^{-1},<75 \mathrm{MJ} \mathrm{kg}^{-1}\right)$ than currently available photocatalysts. PR efficiency also plays a significant role: adjusting the $\mathrm{H}_{2}$ evolution rate from 0.002 to 0.008 mol $_{2} \mathrm{~g}_{\text {sub }}{ }^{-1} \mathrm{~h}^{-1}$ decreases $\mathrm{H}_{2}$ production cost by $76 \%$ and improves EROI by four times. Note that the "base case" $\mathrm{H}_{2}$ production rate $\left(0.004 \mathrm{~mol}_{\mathrm{H}_{2}} \mathrm{~g}_{\mathrm{sub}}{ }^{-1} \mathrm{~h}^{-1}\right)$ is $50-50,000$ times higher than efficiencies reported in the literature for $\mathrm{PR}$ of real waste in $\mathrm{H}_{2} \mathrm{O}$, but as little as ten times higher than PR coupled with enzymatic ${ }^{38,39}$ or alkaline ${ }^{29}$ pre-treatment, and only two times higher than PR with simple molecules like methanol ${ }^{9}$. Photocatalytic efficiency is also dependent on light intensity, and adjusting the available sunlight from 0.1 to 2 sun thus has a marked impact on PR feasibility. Additional beneficial measures include utilising higher waste concentrations, constructing the plant in a location with long days (e.g. Arizona, USA, with an average of $11 \mathrm{~h}$ of sunlight per day), extending plant lifetime to 20 years, and adjusting 
the waste pre-treatment to use renewable energy sources such as solar heating. Water reuse has the least effect on PR feasibility, although this will likely be location-dependent.

The impact of conducting PR in $1 \mathrm{M} \mathrm{NaOH}$ was also investigated. As mentioned above, alkaline conditions are often employed to enhance waste solubilisation and PR efficiency. Disposal of highly corrosive solutions is nonetheless problematic, and accounts for $86-95 \%$ of operating cost, carbon footprint and embodied energy of PR in $\mathrm{NaOH}$ (Supplementary Figure 1). Even if the $\mathrm{NaOH}$ is recycled 60 times, the cost and EROI of the system fail to reach those of "base case" $\mathrm{PR}$ in $\mathrm{H}_{2} \mathrm{O}$ (Fig. 3b). It is therefore unlikely that $\mathrm{PR}$ in $\mathrm{NaOH}$ will ever be economically, environmentally or energetically favourable, unless it is coupled to waste streams that are already highly alkaline (e.g. paper mills).

While carbon footprints can estimate process sustainability, other indicators should also be assessed for a more holistic overview. For a water-based and sunlight-driven technology like PR, water and land usage are of interest. PR currently requires a large excess of water: $\sim 140 \mathrm{~L}_{\mathrm{H}_{2} \mathrm{O}} \mathrm{kg}_{\mathrm{H}_{2}}{ }^{-1}$ for the "base case." While this may improve to $15-20 \mathrm{~L}_{\mathrm{H}_{2} \mathrm{O}} \mathrm{kg}_{\mathrm{H}_{2}}{ }^{-1}$ in an optimistic scenario, the water footprint is still high in comparison to steam reforming $\left(\sim 4-5 \mathrm{~L}_{2} \mathrm{O}\right.$ $\left.\mathrm{kg}_{\mathrm{H}_{2}}{ }^{-1}\right)$ or electrolysis $\left(\sim 10 \mathrm{~L}_{\mathrm{H}_{2} \mathrm{O}} \mathrm{kg}_{\mathrm{H}_{2}}{ }^{-1}\right) .{ }^{4}$ Access to abundant and sustainable water sources will be crucial for a PR plant, unless seawater proves to be a viable solvent. The land usage of $\mathrm{PR}$ is more competitive, producing $160 \mathrm{~W} \mathrm{~m}^{-2}$ in the base case. While this value varies between 3-250 $\mathrm{W} \mathrm{m}^{-2}$ depending on PR efficiency, it is still comparable to photovoltaics (4-13 $\mathrm{W} \mathrm{m}^{-2}$ ) and the lower end of natural gas combustion $\left(100-1500 \mathrm{~W} \mathrm{~m}^{-2}\right) \cdot{ }^{60}$ All of these metrics - cost, carbon footprint, water footprint, land use and EROI - and their potential trade-offs must be kept in mind when optimising parameters in order to develop a PR process that is both economically-viable and environmentally-friendly.

The analysis thus far has not considered the extraction or sale of organic chemicals, as it is difficult to assume a given product purity and concentration when current PR research has yet to demonstrate selective oxidation to value-added chemicals. However, it is still important to understand the role that oxidation products might play in a future PR process. Fig. $3 \mathrm{c}$ shows 
the energy content of an organic product versus the energy required to separate it by conventional distillation at different PR conversion rates (\% of hydrogen available in the system that is released as $\mathrm{H}_{2}$ gas each day) and substrate concentrations. Once this ratio passes one, it becomes worthwhile to extract the chemical. For a lower energy content molecule such as formic acid, the breakeven point is only surpassed at high substrate concentrations ( $>0.35 \mathrm{~kg} \mathrm{~L}^{-1}, \sim 10$ times higher than that used in the previous analysis) and conversions ( $>30 \%$ per day). While distillation of higher energy content molecules like ethanol can be achieved more easily (waste concentration $>0.075 \mathrm{~kg} \mathrm{~L}^{-1}$, conversion $>8 \%$ per day), significant improvements in oxidation selectivity, as well as substrate solubilisation and catalyst efficiency, must still be made for product extraction from PR to be viable. If the overall PR rate remains low, high value chemicals such as pharmaceutical components would need to be produced in order to reap significant economic benefits (Fig. 3d). For example, oxidising biomass to 3-hydroxybutyrolactone (3-HBL), a precursor for chiral drugs, could reduce the cost of $\mathrm{H}_{2}$ production to $£ 3 \mathrm{~kg}^{-1}$ at PR conversions as low as $0.2 \%$ per day (not considering chemical extraction and purification costs). The generation of aqueous oxidation products would also reduce the carbon footprint by up to $58 \%$ for "base-case" PR in $\mathrm{H}_{2} \mathrm{O}$, as the chemicals act as a carbon sink to prevent the release of $\mathrm{CO}_{2}$ into the atmosphere. Although selectively producing complex molecules may prove difficult given the variability of real waste streams, it could greatly enhance overall PR viability.

Figure 3. Feasibility of pilot scale photoreforming. (a) Model photoreforming pilot plant capable of processing $4000 \mathrm{~L}$ of solution and $100-300 \mathrm{~kg}$ of waste per day over $12 \mathrm{~kg}$ of $\mathrm{CN}_{x} \mid \mathrm{Ni}_{2} P$ in $400 \mathrm{~m}^{2}$. (b) Sensitivity analysis of $\mathrm{H}_{2}$ production cost, carbon footprint and energy returned on invested (EROI) upon variation of individual parameters between low (blue) and high (red) estimates. The round circles in "catalyst reuse" show the effect of utilising a more expensive photocatalyst $\left(\mathrm{TiO}_{2} \mid \mathrm{Pt}\right)$. Calculations are based on PR in $\mathrm{H}_{2} \mathrm{O}$; PR in $1 \mathrm{M} \mathrm{NaOH}$ is only studied in the final entry "NaOH reuse". See Supplementary Tables 10-13 and Supplementary Methods for further details. (c) The ratio of energy contained within an organic product versus energy required for its distillation at different photoreforming conversion efficiencies and waste concentrations. (d) Price of the organic product needed to reduce $\mathrm{H}_{2}$ cost to $£ 3 \mathrm{~kg}^{-1}$ at different daily conversions and substrate-to-product molar ratios; energy required for product extraction is not taken into consideration. 
343 Comparison to other waste-to-fuel technologies highlights some of the advantages and 344 disadvantages of PR (Table 1, Supplementary Table 14, Supplementary Discussion). 345 Although incineration is used to generate energy from $22 \%$ of MSW in high income countries, ${ }^{5}$ 346 it will not be discussed here as we focus specifically on the production of fuels and valueadded chemicals. Of the available waste-to-fuel technologies, gasification and pyrolysis are already used industrially. These endothermic processes use high temperatures to convert biomass, plastic or municipal waste into a gas mixture (syngas, gasification) or synthetic crude oil (pyrolysis). ${ }^{61,62}$ The incoming waste feedstock must be relatively dry (<15\% moisture), ${ }^{33}$ and additional steps are needed to upgrade syngas into $\mathrm{H}_{2}$ or other fuels, or to further process the crude oil. ${ }^{61,62}$ Although PR cannot currently compete economically with gasification or pyrolysis, it benefits from low energy requirements that can be supplied by sunlight, compatibility with wet waste, minimal purification of $\mathrm{H}_{2}$, non-production of high global warming potential gases like $\mathrm{CH}_{4}$, and a comparatively simple reactor setup. metabolise biomass or food waste (plastics are not compatible). ${ }^{63}$ Although fermentation is already used industrially for biogas or ethanol production, $\mathrm{H}_{2}$ generation is still in the up-scaling phase. ${ }^{63}$ The $\mathrm{H}_{2}$ price is resultantly high, and comparable to that predicted for a pilot-scale PR plant. Fermentation is also increasingly used to generate fine chemicals such as levulinic acid or succinic acid from biomass or food waste.$^{64,65}$ Fermentation and PR rely on similar process conditions - low temperatures, slow reaction rates, aqueous medium, production of both gaseous and liquid chemicals - and lessons learned during up-scaling of fermentation may be applicable to PR.

As with all components of a carbon-zero future, successfully recapturing the energetic and chemical value in waste will require a combination of different technologies working in synergy. The relatively simple setup and versatility of PR could be particularly beneficial for small-scale, decentralised applications in which the waste feedstock and $\mathrm{H}_{2}$ application are 

and engineers develop PR as a complete system - waste collection, pre-treatment,

371 photocatalysis, liquid disposal or recycling, and product distribution - rather than focussing exclusively on the photocatalytic step.

Table 1. Comparison of photoreforming to alternative waste-to-fuel technologies. $M S W=$ municipal solid waste. See Supplementary Table 14 and Supplementary Discussion for more details.

\begin{tabular}{|c|c|c|c|c|c|}
\hline & Gasification & Pyrolysis & Fermentation & $\begin{array}{l}\text { Waste-to- } \\
\text { chemical }\end{array}$ & Photoreforming \\
\hline Feedstock & $\begin{array}{l}\text { Biomass, mixed } \\
\text { plastic, MSW }\end{array}$ & $\begin{array}{l}\text { Biomass, mixed } \\
\text { plastic, MSW }\end{array}$ & Biomass, food & Biomass, food & $\begin{array}{l}\text { Biomass, polar } \\
\text { plastic, food, } \\
\text { MSW }\end{array}$ \\
\hline Temp. $\left({ }^{\circ} \mathrm{C}\right)$ & $600-1000$ & $300-900$ & $25-70$ & $37-220$ & $10-60$ \\
\hline $\begin{array}{l}\text { Products } \\
\text { (and side } \\
\text { products) }\end{array}$ & $\begin{array}{c}\mathrm{H}_{2} \\
\left(\mathrm{CH}_{4}, \mathrm{CO}, \mathrm{CO}_{2}\right. \\
\text { ash, tar })\end{array}$ & $\begin{array}{c}\text { Bio/synthetic } \\
\text { crude oil } \\
\text { (ash, char) }\end{array}$ & $\begin{array}{c}\mathrm{H}_{2} \\
\text { ( } \mathrm{CH}_{4}, \mathrm{CO}_{2}, \mathrm{NH}_{3}, \\
\text { organics, solids) }\end{array}$ & $\begin{array}{l}\text { Levulinic acid } \\
\text { (formic acid) or } \\
\text { succinic acid } \\
\text { (liquid waste) }\end{array}$ & $\begin{array}{c}\mathrm{H}_{2} \\
\left(\mathrm{CO}_{2} \text {, organics) }\right.\end{array}$ \\
\hline $\begin{array}{l}\text { Price } \\
\text { (£ / GJ product) }\end{array}$ & $9-42$ & $1-31$ & $11-380$ & $\begin{array}{c}1.3-6.5 / \mathrm{kg} \text { acidic } \\
\text { product }\end{array}$ & $\begin{array}{c}60-290 \\
\text { (pilot scale) }\end{array}$ \\
\hline $\begin{array}{l}\text { Carbon } \\
\text { Footprint } \\
\text { (g CO } \mathrm{g} \mathrm{O}_{2} \text {-eq) }\end{array}$ & $\begin{array}{c}13-124 / \\
\mathrm{MJ} \mathrm{H}_{2}\end{array}$ & $\begin{array}{l}10-85 / \\
\text { MJ crude }\end{array}$ & $\begin{array}{l}28-5000 / \\
\mathrm{MJ} \mathrm{H}_{2}\end{array}$ & $\begin{array}{l}-800-5300 / \\
\mathrm{kg} \text { acid }\end{array}$ & $\begin{array}{l}35-125 / \\
\mathrm{MJ} \mathrm{H}_{2}\end{array}$ \\
\hline TRL (1-9) & $6-8$ & $5-8$ & $5-6$ & $7-8$ & $3-4$ \\
\hline Advantages & $\begin{array}{l}\text { - Fast } \\
\text { - High yields } \\
\text { - Industrial scale }\end{array}$ & $\begin{array}{l}\text { - Compatible with } \\
\text { many wastes } \\
\text { - Product } \\
\text { compatible with } \\
\text { existing fuel } \\
\text { infrastructure }\end{array}$ & $\begin{array}{l}\text { - Bio-based and } \\
\text { low energy use } \\
\text { - Compatible with } \\
\text { wet waste } \\
\text { - Low capital cost }\end{array}$ & $\begin{array}{l}\text { - High yields of } \\
\text { high-value } \\
\text { products } \\
\text { - Fast }\end{array}$ & $\begin{array}{l}\text { - Compatible with } \\
\text { mixed and wet } \\
\text { wastes } \\
\text { - Sunlight-driven, } \\
\text { low temperature } \\
\text { - Pure } \mathrm{H}_{2} \text { stream } \\
\text { - Simple setup } \\
\end{array}$ \\
\hline Disadvantages & $\begin{array}{l}\text { - High } \\
\text { temperature } \\
\text { - Needs dry waste } \\
\text { - Post-treatment } \\
\text { to purify gas } \\
\text { - High capital cost }\end{array}$ & $\begin{array}{l}\text { - High } \\
\text { temperature } \\
\text { - Different wastes } \\
\text { yield different oil } \\
\text { compositions } \\
\text { - Post-treatment } \\
\text { to purify oil }\end{array}$ & $\begin{array}{l}\text { - Not compatible } \\
\text { with plastic or } \\
\text { mixed waste } \\
\text { - Pilot-scale } \\
\text { - Slow }\end{array}$ & $\begin{array}{l}\text { - Needs well- } \\
\text { defined waste } \\
\text { streams } \\
\text { - Plastic waste is } \\
\text { less studied }\end{array}$ & $\begin{array}{l}\text { - Still lab-scale } \\
\text { - Low yields } \\
\text { - Slow }\end{array}$ \\
\hline References & $66-75$ & $62,76-83$ & $63,84-89$ & $64,65,90-93$ & this work \\
\hline
\end{tabular}

\section{Future research directions}

377 Five key areas for future PR research can be identified from this feasibility analysis (Fig. 4).

First, solubilisation of the waste feedstock can greatly improve efficiency. However, the alkaline pre-treatments commonly reported for PR are unlikely to be feasible on a large scale due to the cost and environmental impact of $\mathrm{NaOH}$ purchase and disposal. High temperature treatments $\left(>50^{\circ} \mathrm{C}\right)$ are also undesirable unless they have short durations or utilise renewable methods such as solar heating. Higher feedstock concentrations (ideally $>0.1 \mathrm{~kg} \mathrm{~L}^{-1}$ ) could increase the volumetric $\mathrm{H}_{2}$ production rate, make organic chemical extraction more feasible, 
and reduce the water impact and capital costs of PR. Less chemically and energetically demanding pre-treatments that can process higher waste concentrations must be developed.

Second, more efficient and durable photocatalysts should be designed. $\mathrm{H}_{2}$ evolution rates must improve by at least fifty times (rates of $>0.004 \mathrm{~mol}_{2} \mathrm{~g}_{\mathrm{sub}}{ }^{-1} \mathrm{~h}^{-1}$, conversions of $>50 \%$ per day, and external quantum yields of $>50 \%$ ) in order for large-scale PR to be economically and environmentally feasible. Efficiencies could be enhanced through various techniques, such as extending visible light absorption, reducing charge recombination, or increasing reaction temperatures with concentrated sunlight or plasmonic materials. Catalyst design for waste PR is limited, with only $\mathrm{TiO}_{2}, \mathrm{CN}_{\mathrm{x}}$ and $\mathrm{CdS}$ reported, but researchers could draw upon water splitting photocatalyst literature ${ }^{94,95}$ The photocatalyst must also be durable - with a lifetime of at least one year - and either recyclable from solution or affixed on a panel that can be directly used in a photoreactor. Catalyst reusability is especially important when precious metal co-catalysts are included. Methods for preventing catalyst deactivation, such as minimising the formation of oxidation intermediates that block catalytic active sites or removing those products in a regeneration procedure, should be investigated.

Photoreactor development will be crucial for up-scaling of PR. This is not a trivial task, as both light absorption and photocatalyst-substrate interaction must be optimised. Two of the most common configurations for photocatalytic processes are flat panel reactors and concentrating reactors (which use parabolic mirrors to concentrate sunlight onto a transparent tube). ${ }^{53}$ Flat panel reactors are simple to design and construct but often have lower efficiencies, whereas concentrating reactors are more complicated but offer enhanced irradiation. ${ }^{53}$ The photocatalyst can be dispersed in solution or immobilised on one of the reactor surfaces; the latter will be beneficial for catalyst reuse as mentioned above. All pilot scale photoreactor setups have been designed for photocatalytic water purification, and the largest examples of photocatalytic $\mathrm{H}_{2}$ production range from 1-100 $\mathrm{m}^{2} .{ }^{96,97}$ While these reactors can be adapted for $\mathrm{PR}$, care must be taken to ensure that they are gas-tight and compatible with tri-phasic flow (liquid water, solid waste particles, $\mathrm{H}_{2}$ gas). 
412 of the process, or a mixture of small organic molecules, which act as carbon sinks but are 413 difficult to extract from solution. Ideally, a future PR process would selectively produce a single 414 high-value oxidation product. There are already several examples of photocatalytic conversion 415 of biomass into value-added chemicals, ${ }^{98-100}$ and PR can learn from and adapt these approaches. Oxidation co-catalysts should also be explored, as these materials could facilitate charge separation and act as reaction sites for the selective transformation of different waste streams. Feedstock variation and product selectivity are not always compatible, and thus there will need to be some degree of compromise between maintaining the versatility of PR and selectively producing organic chemicals.

Finally, PR has currently been used exclusively for $\mathrm{H}_{2}$ production, but it has potential as a diverse platform for other useful chemical processes. In theory, PR could be coupled with $\mathrm{CO}_{2}$ reduction to $\mathrm{CO}$ or other fuel building blocks, nitrogen fixation in ammonia, or even the reduction of metals in wastewaters or electronic waste.

Figure 4. Recommended future research areas for waste photoreforming.

In summary, nature regenerates unneeded materials into energy and nutrients, and humanity can adopt this strategy to chemically recycle waste and develop a circular economy. Most waste is rich in energy and chemical composition and should be considered an attractive feedstock, which has motivated its use in photoreforming. Photoreforming can transform many components of waste - especially biomass, food and plastic - into $\mathrm{H}_{2}$ fuel and organic chemicals using sunlight as the sole energy input. Preliminary techno-economic and life cycle assessments of photoreforming indicated that its carbon footprint is already lower than or comparable to existing methods for $\mathrm{H}_{2}$ production, waste-to-fuel conversion and waste management, although the production cost and energy balance require further improvement before industrial application can be envisaged. Major contributors to the economic and environmental feasibility of photoreforming were identified, namely substrate pre-treatment 
and concentration, photocatalyst efficiency and durability, water usage and organic chemical production. Reactor design and the coupling of photoreforming with alternative reduction reactions were also recommended as future areas of research. With continued technological developments and application in tandem with other renewable technologies, photoreforming has the potential to not only generate clean fuels and mitigate waste, but also contribute to the circular and sustainable flow of materials and energy in a carbon-zero future.

\section{Acknowledgements}

445 This work was supported by the Cambridge Creative Circular Plastics Centre (CirPlas, EP/S025308/1), EPSRC (NanoDTC, EP/L015978/1 and EP/S022953), the Austrian Science Fund (Schrödinger Scholarship J-4381), Erasmus, and the OMV Group. We thank Dr Qian Wang, Dr Tengfei Li, and i-Teams (Alexander Sneyd, Amy Weatherup, Brett Gutstein, Cameron Holloway, Dante Elio D’Orazio, Dominic Caddick, Edna Soto-Ruiz, Jason Teo, Jeremy Carey, Jiayu Qiu, Dr. Lara Allen, Made Santihayu Sukma, Dr Mark Priest, Saffy Admad, Tahmida Najmatul Huq, Zhimian Hao) for useful discussions.

\section{Author Information}

Affiliations

Department of Chemistry, University of Cambridge, Lensfield Road, Cambridge CB2 1EW,

456 UK - Taylor Uekert, Christian M. Pichler, Teresa Schubert, Erwin Reisner

\section{$457 \quad$ Contributions}

458 T.U. and E.R. designed the review, T.U. and T.S. performed the feasibility analysis, C.M.P. prepared the alternative technologies tables and discussion and T.U. developed all other figures and tables. All authors contributed to the writing of the manuscript and approved the final version.

\section{Corresponding author}

463 Correspondence to Erwin Reisner (reisner@ch.cam.ac.uk). 


\section{Ethical Declarations}

467 Competing interests

A patent application on photoreforming with carbonaceous photocatalysts has been filed by

Cambridge Enterprise (WO 2019/229255).

470

471

\section{References}

472

1. Ellen MacArthur Foundation. Towards the Circular Economy: Economic and Business Rationale for an Accelerated Transition. (EMF, 2013).

2. Ellen MacArthur Foundation. Completing the Picture: How the Circular Economy Tackles Climate Change. (EMF, 2019).

3. International Energy Agency. World Energy Outlook 2018. (IEA, 2018).

4. International Energy Agency. The Future of Hydrogen: Seizing Today's Opportunities. (IEA, 2019).

5. Kaza, S., Yao, L., Bhada-Tata, P. \& Van Woerden, F. What a Waste 2.0 - A Global Snapshot of

6. Kawai, T. \& Sakata, T. Conversion of carbohydrate into hydrogen fuel by a photocatalytic process. Nature 286, 474-476 (1980).

7. Kawai, T. \& Sakata, T. Photocatalytic hydrogen production from water by the decomposition of poly-vinylchloride, protein, algae, dead insects, and excrement. Chem. Lett. 81-84 (1981).

8. Sakata, T. \& Kawai, T. Photodecomposition of Water by Using Organic Compounds. Hydrogen Evolution by Powdered Semiconductor Photocatalysts. J. Syn. Org. Chem. Jpn. 39, 589-602 (1981).

9. Puga, A.V. Photocatalytic production of hydrogen from biomass-derived feedstocks. Coord. Chem. Rev. 315, 1-66 (2016).

10. Chen, S., Takata, T. \& Domen, K. Particulate photocatalysts for overall water splitting. Nat. Rev. Mater. 2, 17050 (2017).

11. Kuehnel, M.F. \& Reisner, E. Solar hydrogen generation from lignocellulose. Angew. Chem. Int. Ed. 57, 3290-3296 (2018).

12. Christoforidis, K.C. \& Fornasiero, P. Photocatalytic hydrogen production: A rift into the future energy supply. ChemCatChem 9, 1523-1544 (2017).

13. Huang, C.W., Nguyen, B.S., Wu, J.C.S. \& Nguyen, V.H. A current perspective for photocatalysis towards the hydrogen production from biomass-derived organic substances and water. Int. J. Hydrog. Energy 45, 18144-18159 (2020).

14. Uekert, T., Kasap, H. \& Reisner, E. Photoreforming of nonrecyclable plastic waste over a carbon nitride/nickel phosphide catalyst. J. Am. Chem. Soc. 141, 15201-15210 (2019).

15. Yang, Y.Z., Chang, C.H. \& Idriss, H. Photo-catalytic production of hydrogen form ethanol over 
$\mathrm{M} / \mathrm{TiO}_{2}$ catalysts $(\mathrm{M}=\mathrm{Pd}$, $\mathrm{Pt}$ or $\mathrm{Rh})$. Appl. Catal. B Environ. 67, 217-222 (2006).

16. Al-Azri, Z.H.N. et al. The roles of metal co-catalysts and reaction media in photocatalytic hydrogen production: Performance evaluation of $\mathrm{M} / \mathrm{TiO}_{2}$ photocatalysts $(\mathrm{M}=\mathrm{Pd}, \mathrm{Pt}, \mathrm{Au}$ ) in different alcohol-water mixtures. J. Catal. 329, 355-367 (2015).

17. Bowker, M., Davies, P.R. \& Al-Mazroai, L.S. Photocatalytic reforming of glycerol over gold and palladium as an alternative fuel source. Catal. Letters 128, 253-255 (2009).

18. United Nations Environment Programme. Global Waste Management Outlook. (UNEP, 2015).

19. Tripathi, N., Hills, C.D., Singh, R.S. \& Atkinson, C.J. Biomass waste utilisation in low-carbon products: harnessing a major potential resource. npj Clim. Atmos. Sci. 2, 35 (2019).

20. Kadam, S.R. et al. A green process for efficient lignin (biomass) degradation and hydrogen production via water splitting using nanostructured $\mathrm{C}, \mathrm{N}, \mathrm{S}$-doped $\mathrm{ZnO}$ under solar light. RSC Adv. 4, 60626-60635 (2014).

21. Wakerley, D.W. et al. Solar-driven reforming of lignocellulose to $\mathrm{H}_{2}$ with a $\mathrm{CdS} \mid \mathrm{CdO} \times$ photocatalyst. Nat. Energy 2, 17021 (2017).

22. Kasap, H., Achilleos, D.S., Huang, A. \& Reisner, E. Photoreforming of lignocellulose into $\mathrm{H}_{2}$ using nanoengineered carbon nitride under benign conditions. J. Am. Chem. Soc. 140, 11604-11607 (2018).

23. Zhou, W. et al. Feasibility of lipid production from waste paper by the oleaginous yeast Cryptococcus curvatus. BioResources 12, 5249-5263 (2017).

24. Food and Agriculture Organization of the United Nations. Fruit and vegetable processing chapter 2 - General properties of fruit and vegetables; chemical composition and nutritional aspects; structural features. Available at: http://www.fao.org/3/V5030E/V5030E05.htm. (Accessed: 30th April 2020)

25. Food and Agriculture Organization of the United Nations. FAO's Animal Production and Health Division: Meat \& Meat Products. Available at: http://www.fao.org/ag/againfo/themes/en/meat/backgr_composition.html. (Accessed: 30th April 2020)

26. Uekert, T., Dorchies, F., Pichler, C.M. \& Reisner, E. Photoreforming of food waste into valueadded products over visible-light-absorbing catalysts. Green Chem. 22, 3262-3271 (2020).

27. Geyer, R., Jambeck, J.R. \& Law, K.L. Production, use, and fate of all plastics ever made. Sci. Adv. 3, e1700782 (2017).

28. Albertsson, A.C. \& Hakkarainen, M. Designed to degrade. Science 358, 872-873 (2017).

29. Uekert, T., Kuehnel, M.F., Wakerley, D.W. \& Reisner, E. Plastic waste as a feedstock for solardriven $\mathrm{H}_{2}$ generation. Energy Environ. Sci. 11, 2853-2857 (2018).

30. Food and Agriculture Organization of the United Nations. Food wastage footprint and climate change. (FAO, 2015).

31. Van Ewijk, S., Stegemann, J.A. \& Ekins, P. Global life cycle paper flows, recycling metrics, and material efficiency. J. Ind. Ecol. 22, 686-693 (2018).

32. Bauer, M. et al. Sink-float density separation of post-consumer plastics for feedstock recycling. J. Mater. Cycles Waste Manag. 20, 1781-1791 (2018). 
33. Ramos, A., Monteiro, E., Silva, V. \& Rouboa, A. Co-gasification and recent developments on waste-to-energy conversion: A review. Renew. Sustain. Energy Rev. 81, 380-398 (2018).

34. Zou, J., Zhang, G. \& Xu, X. One-pot photoreforming of cellulosic biomass waste to hydrogen by merging photocatalysis with acid hydrolysis. Appl. Catal. A Gen. 563, 73-79 (2018).

35. Jaswal, R., Shende, R., Nan, W. \& Shende, A. Photocatalytic reforming of pinewood (Pinus ponderosa) acid hydrolysate for hydrogen generation. Int. J. Hydrog. Energy 42, 2839-2848 (2017).

36. Kida, T. et al. Hydrogen production from sewage sludge solubilized in hot-compressed water using photocatalyst under light irradiation. Int. J. Hydrog. Energy 29, 269-274 (2004).

37. Pichler, C.M., Uekert, T. \& Reisner, E. Photoreforming of biomass in metal salt hydrate solutions. Chem. Commun. 56, 5743-5746 (2020).

38. Shiragami, T., Tomo, T., Tsumagari, H., Ishii, Y. \& Yasuda, M. Hydrogen evolution from napiergrass by the combination of biological treatment and a Pt-loaded $\mathrm{TiO}_{2}$-photocatalytic reaction. Catalysts 2, 56-67 (2012).

39. Yasuda, M., Kurogi, R., Tsumagari, H., Shiragami, T. \& Matsumoto, T. New approach to fuelization of herbaceous lignocelluloses through simultaneous saccharification and fermentation followed by photocatalytic reforming. Energies 7, 4087-4097 (2014).

40. Melchionna, M. \& Fornasiero, P. Updates on the roadmap for photocatalysis. ACS Catal. 10, 5493-5501 (2020).

41. Speltini, A. et al. Sunlight-promoted photocatalytic hydrogen gas evolution from water-suspended cellulose: a systematic study. Photochem. Photobiol. Sci. 13, 1410-1419 (2014).

42. Zhou, Y., Ye, X. \& Lin, D. Enhance photocatalytic hydrogen evolution by using alkaline pretreated corn stover as a sacrificial agent. Int. J. Energy Res. 44, 4616-4628 (2020).

43. Caravaca, A., Jones, W., Hardacre, C. \& Bowker, M. $\mathrm{H}_{2}$ production by the photocatalytic reforming of cellulose and raw biomass using $\mathrm{Ni}, \mathrm{Pd}, \mathrm{Pt}$ and $\mathrm{Au}$ on titania. Proc. R. Soc. A Math. Phys. Eng. Sci. 472, 20160054 (2016).

44. Speltini, A. et al. Swine sewage as sacrificial biomass for photocatalytic hydrogen gas production: Explorative study. Int. J. Hydrog. Energy 39, 11433-11440 (2014).

45. Speltini, A. et al. Evaluation of UV-A and solar light photocatalytic hydrogen gas evolution from olive mill wastewater. Int. J. Hydrog. Energy 40, 4303-4310 (2015).

46. Speltini, A. et al. Photocatalytic hydrogen evolution assisted by aqueous (waste)biomass under simulated solar light: Oxidized g- $\mathrm{C}_{3} \mathrm{~N}_{4}$ vs. P25 titanium dioxide. Int. J. Hydrog. Energy 44, 40724078 (2019).

47. Sanwald, K.E. et al. Overcoming the rate-limiting reaction during photoreforming of sugar aldoses for $\mathrm{H}_{2}$-generation. ACS Catal. 7, 3236-3244 (2017).

48. Tapia-Venegas, E. et al. Biohydrogen production by dark fermentation: scaling-up and technologies integration for a sustainable system. Rev. Environ. Sci. 14, 761-785 (2015).

49. Li, D., Yu, J.C.C., Nguyen, V.H., Wu, J.C.S. \& Wang, X. A dual-function photocatalytic system for simultaneous separating hydrogen from water splitting and photocatalytic degradation of phenol in a twin-reactor. Appl. Catal. B Environ. 239, 268-279 (2018). 
50. Wang, Y. et al. Direct and indirect Z-scheme heterostructure-coupled photosystem enabling cooperation of $\mathrm{CO}_{2}$ reduction and $\mathrm{H}_{2} \mathrm{O}$ oxidation. Nat. Commun. 11, 1-11 (2020).

51. Greenblatt, J.B., Miller, D.J., Ager, J.W., Houle, F.A. \& Sharp, I.D. The technical and energetic challenges of separating (photo)electrochemical carbon dioxide reduction products. Joule 2, 381420 (2018).

52. Sathre, R. et al. Life-cycle net energy assessment of large-scale hydrogen production via photoelectrochemical water splitting. Energy Environ. Sci. 7, 3264-3278 (2014).

53. Braham, R. J. \& Harris, A. T. Review of major design and scale-up considerations for solar photocatalytic reactors. Ind. Eng. Chem. Res. 48, 8890-8905 (2009).

54. Hydrogen Council. Path to hydrogen competitiveness: A cost perspective. (2020).

55. Pinaud, B.A. et al. Technical and economic feasibility of centralized facilities for solar hydrogen production via photocatalysis and photoelectrochemistry. Energy Environ. Sci. 6, 1983-2002 (2013).

56. Shaner, M.R., Atwater, H.A., Lewis, N.S. \& Mcfarland, E.W. A comparative technoeconomic analysis of renewable hydrogen production using solar energy. Energy Environ. Sci 9, 2371 (2016).

57. Tribe, M.A. \& Alpine, R.L.W. Scale Economies and the '0.6 Rule'. Eng. Costs Prod. Econ. 10, 271-278 (1986).

58. Spath, P.L. \& Mann, M.K. Life Cycle Assessment of Hydrogen Production via Natural Gas Steam Reforming. (National Renewable Energy Laboratory, 2001).

59. ARUP \& De Montfort University. Measuring scope 3 carbon emissions-water and waste. (2012).

60. Van Zalk, J. \& Behrens, P. The spatial extent of renewable and non-renewable power generation: A review and meta-analysis of power densities and their application in the U.S. Energy Policy 123, 83-91 (2018).

61. Okolie, J.A., Nanda, S., Dalai, A.K., Berruti, F. \& Kozinski, J.A. A review on subcritical and supercritical water gasification of biogenic, polymeric and petroleum wastes to hydrogen-rich synthesis gas. RRenew. Sust. Energ. Rev. 119, 109546 (2020).

62. Sharifzadeh, M. et al. The multi-scale challenges of biomass fast pyrolysis and bio-oil upgrading: Review of the state of art and future research directions. Prog. Energy Combust. Sci. 71, 1-80 (2019).

63. Yun, Y.M. et al. Biohydrogen production from food waste: Current status, limitations, and future perspectives. Bioresour. Technol. 248, 79-87 (2018).

64. Hayes, D.J., Fitzpatrick, S., Hayes, M.H.B. \& Ross, J.R.H. The Biofine Process- Production of Levulinic Acid, Furfural, and Formic Acid from Lignocellulosic Feedstocks. in BiorefineriesIndustrial Processes and Products (eds. Kamm, B., Gruber, P.R., Kamm, M.) Chapter 7, 139-164 (Wiley-VCH Verlag GmbH, 2008).

65. Jansen, M.L.A. \& van Gulik, W.M. Towards large scale fermentative production of succinic acid. Curr. Opin. Biotech. 30, 190-197 (2014).

66. Lopez, G. et al. Recent advances in the gasification of waste plastics. A critical overview. Renew. Sustain. Energy Rev. 82, 576-596 (2018). 
67. Molino, A., Larocca, V., Chianese, S. \& Musmarra, D. Biofuels Production by Biomass Gasification: A Review. Energies 11, 811 (2018).

68. Lombardi, L., Carnevale, E. \& Corti, A. A review of technologies and performances of thermal treatment systems for energy recovery from waste. Waste Manag. 37, 26-44 (2015).

69. Binder, M., Kraussler, M., Kuba, M. \& Luisser, M. Hydrogen from biomass gasification. (IEA Bioenergy, 2018).

70. Couto, N., Silva, V., Monteiro, E. \& Rouboa, A. Exergy analysis of Portuguese municipal solid waste treatment via steam gasification. Energy Convers. Manag. 134, 235-246 (2017).

71. Wulf, C. \& Kaltschmitt, M. Life cycle assessment of biohydrogen production as a transportation fuel in Germany. Bioresour. Technol. 150, 466-475 (2013).

72. Moreno, J. \& Dufour, J. Life cycle assessment of hydrogen production from biomass gasification. Evaluation of different Spanish feedstocks. Int. J. Hydrog. Energy 38, 7616-7622 (2013).

73. Khoo, H.H. LCA of plastic waste recovery into recycled materials, energy and fuels in Singapore. Resour. Conserv. Recycl. 145, 67-77 (2019).

74. Erkiaga, A., Lopez, G., Amutio, M., Bilbao, J. \& Olazar, M. Syngas from steam gasification of polyethylene in a conical spouted bed reactor. Fuel 109, 461-469 (2013).

75. Shahabuddin, M., Krishna, B.B., Bhaskar, T. \& Perkins, G. Advances in the thermo-chemical production of hydrogen from biomass and residual wastes: Summary of recent techno-economic analyses. Bioresour. Technol. 299, 122557 (2020).

76. Lopez, G., Artetxe, M., Amutio, M., Bilbao, J. \& Olazar, M. Thermochemical routes for the valorization of waste polyolefinic plastics to produce fuels and chemicals. A review. Renew. Sust. Energ. Rev. 73, 346-368 (2017).

77. Guedes, R.E., Luna, A.S. \& Torres, A.R. Operating parameters for bio-oil production in biomass pyrolysis: A review. J. Anal. Appl. Pyrol. 129, 134-149 (2018).

78. Qureshi, K.M., Kay Lup, A.N., Khan, S., Abnisa, F. \& Wan Daud, W.M.A. A technical review on semi-continuous and continuous pyrolysis process of biomass to bio-oil. J. Anal. Appl. Pyrol. 131, 52-75 (2018).

79. Benavides, P.T., Sun, P., Han, J., Dunn, J.B. \& Wang, M. Life-cycle analysis of fuels from postuse non-recycled plastics. Fuel 203, 11-22 (2017).

80. Fivga, A. \& Dimitriou, I. Pyrolysis of plastic waste for production of heavy fuel substitute: A technoeconomic assessment. Energy 149, 865-874 (2018).

81. Rogers, J.G. \& Brammer, J.G. Estimation of the production cost of fast pyrolysis bio-oil. Biomass Bioenerg. 36, 208-217 (2012).

82. Brigagão, G.V., de Queiroz Fernandes Araújo, O., de Medeiros, J.L., Mikulcic, H. \& Duic, N. A techno-economic analysis of thermochemical pathways for corncob-to-energy: Fast pyrolysis to bio-oil, gasification to methanol and combustion to electricity. Fuel Process. Technol. 193, 102113 (2019).

83. Qureshi, M.S., et al. Pyrolysis of plastic waste: Opportunities and challenges. J. Anal. Appl. Pyrolysis 148, 104804 (2020).

84. Tian, H. et al. Organic waste to biohydrogen: A critical review from technological development 
and environmental impact analysis perspective. Appl. Energy 256, 113961 (2019).

85. Jarunglumlert, T., Prommuak, C., Putmai, N. \& Pavasant, P. Scaling-up bio-hydrogen production from food waste: Feasibilities and challenges. Int. J. Hydrog. Energy 43, 634-648 (2018).

86. Djomo, S.N. \& Blumberga, D. Comparative life cycle assessment of three biohydrogen pathways. Bioresour. Technol. 102, 2684-2694 (2011).

87. Manish, S. \& Banerjee, R. Comparison of biohydrogen production processes. Int. J. Hydrog. Energy 33, 279-286 (2008).

88. Ljunggren, M., Wallberg, O. \& Zacchi, G. Techno-economic comparison of a biological hydrogen process and a 2nd generation ethanol process using barley straw as feedstock. Bioresour. Technol. 102, 9524-9531 (2011).

89. Han, W., Fang, J., Liu, Z. \& Tang, J. Techno-economic evaluation of a combined bioprocess for fermentative hydrogen production from food waste. Bioresour. Technol. 202, 107-112 (2016).

90. Cho, E.J., Trinh, L.T.P., Song, Y., Lee, Y.G. \& Bae, H.J. Bioconversion of biomass waste into high value chemicals. Bioresour. Technol. 298, 122386 (2020).

91. Zhang, A.Y.Z. et al. Valorisation of bakery waste for succinic acid production. Green Chem. 15, 690-695 (2013).

92. Hermann, B.G. \& Patel, M. Today's and tomorrow's bio-based bulk chemicals from white biotechnology: A techno-economic analysis. Appl. Biochem. Biotechnol. 136, 361-388 (2007).

93. Morales, M. et al. Sustainability assessment of succinic acid production technologies from biomass using metabolic engineering. Energy Environ. Sci. 9, 2794-2805 (2016).

94. Takanabe, K. Photocatalytic water splitting: Quantitative approaches toward photocatalyst by design. ACS Catal. 7, 8006-8022 (2017).

95. Wang, Q. \& Domen, K. Particulate photocatalysts for light-driven water splitting: Mechanisms, challenges, and design strategies. Chem. Rev. 120, 919-985 (2020).

96. Schröder, M. et al. Hydrogen evolution reaction in a large-scale reactor using a carbon nitride photocatalyst under natural sunlight irradiation. Energy Technol. 3, 1014-1017 (2015).

97. Wei, Q. et al. Direct solar photocatalytic hydrogen generation with CPC photoreactors: System development. Sol. Energy 153, 215-223 (2017).

98. Isikgor, F.H. \& Remzi Becer, C. Lignocellulosic biomass: a sustainable platform for the production of bio-based chemicals and polymers. Polym. Chem 6, 4497 (2015).

99. Wu, X. et al. Solar energy-driven lignin-first approach to full utilization of lignocellulosic biomass under mild conditions. Nat. Catal. 1, 772-780 (2018).

100. Huang, Z. et al. Enhanced photocatalytic alkane production from fatty acid decarboxylation via inhibition of radical oligomerization. Nat. Catal. 3, 170-178 (2020). 


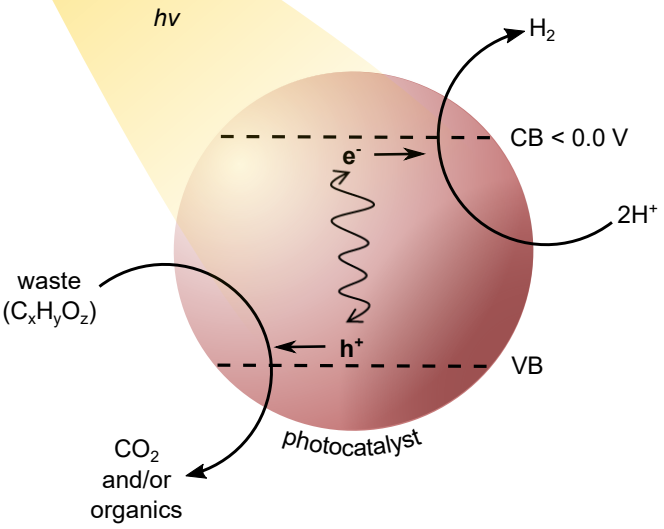




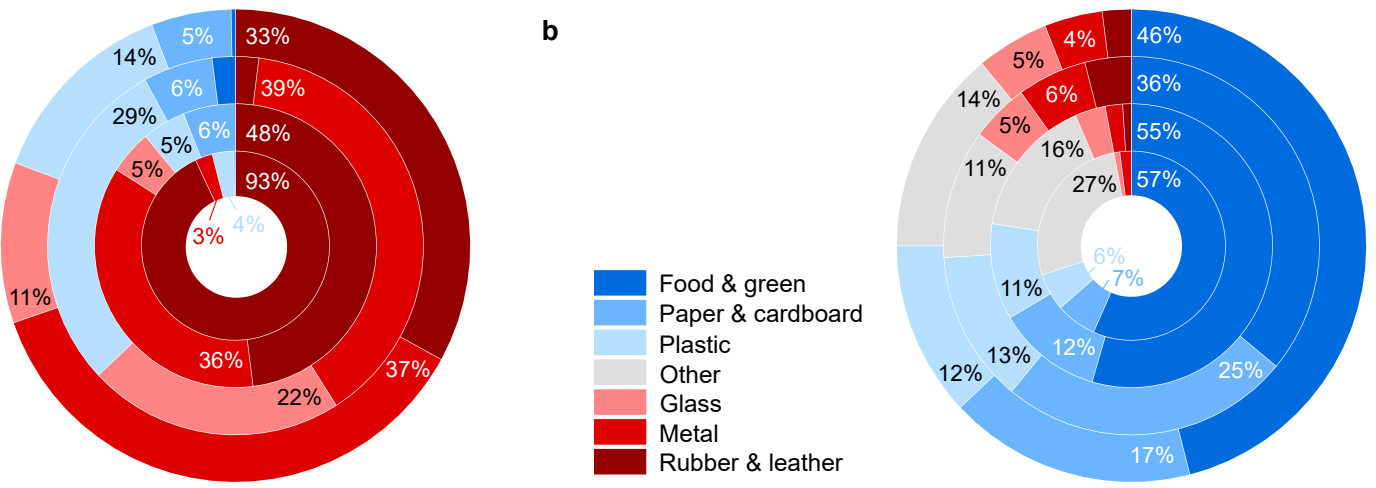

c
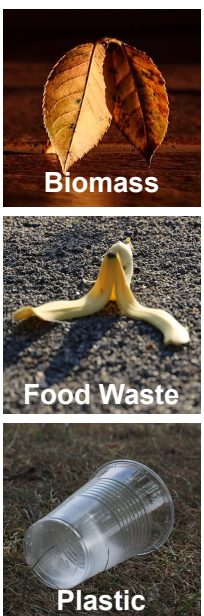

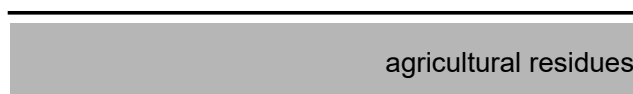

accessible for

PR: 55-95 wt\%

$\begin{array}{cc}\text { cellulose } & \text { hemicellulose } \\ \left(\mathrm{C}_{6} \mathrm{H}_{10} \mathrm{O}_{5}\right)_{\mathrm{n}} & \left(\mathrm{C}_{5} \mathrm{H}_{10} \mathrm{O}_{5}\right)_{\mathrm{n}}\end{array}$

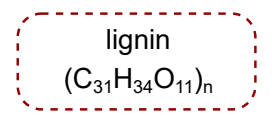

wood residues

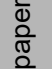

cereals \& starchy roots

\section{fruit \& vegetables}

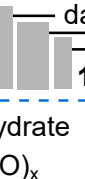

meat \& fish

oilcrops

accessible for carbohydrate protein

fat

PR: $10-80$ wt $\%$

$\left(\mathrm{CH}_{2} \mathrm{O}\right)_{x}$

$\mathrm{C}_{400} \mathrm{H}_{620} \mathrm{~N}_{100} \mathrm{O}_{120} \mathrm{PS}$

$\mathrm{CH}_{3}\left(\mathrm{CH}_{2}\right)_{\mathrm{n}} \mathrm{COOH}$

inaccessible for PR: $20-90$ wt $\%$

non-
polar $\frac{\text { polar }}{302}$ other

accessible for PR: 16-17 wt\% non-polar polymers

e.g. $\left(\mathrm{C}_{2} \mathrm{H}_{4}\right)_{n},\left(\mathrm{C}_{8} \mathrm{H}_{8}\right)_{n},\left(\mathrm{C}_{3} \mathrm{H}_{6}\right)_{n}$ inaccessible for PR: 5-45 wt\% inaccessible for PR: 83-84 wt \% 
mixed waste $(100-300 \mathrm{~kg})$

(15-45 kg)

pre-treatment: heat $\left(40-80{ }^{\circ} \mathrm{C}\right)$ and/or chemical

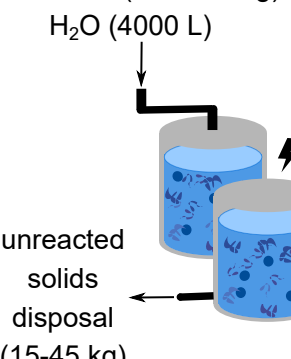

liquid waste

disposal

(4000 L)

compression

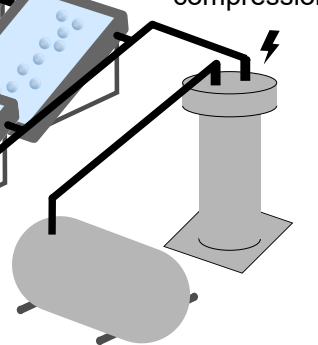

$\mathrm{H}_{2}$ storage photoreforming
(400 m², $12 \mathrm{~kg}$ photocatalyst)

\section{Key Takeaways:}

1. PR efficiency must improve by $>50 x$ to be viable.

2. Catalyst reusability $>1 \mathrm{yr}$ is essential and more important than catalyst cost

3. Less chemically-harsh and lower energy pre-treatments that can handle high waste concentrations are needed.

4. Selectivity towards high value organic products could improve future PR economics. b

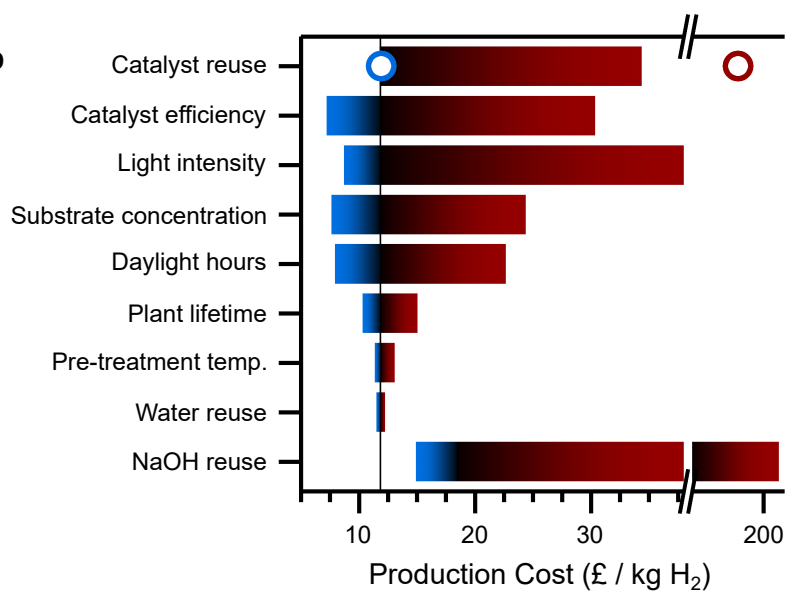

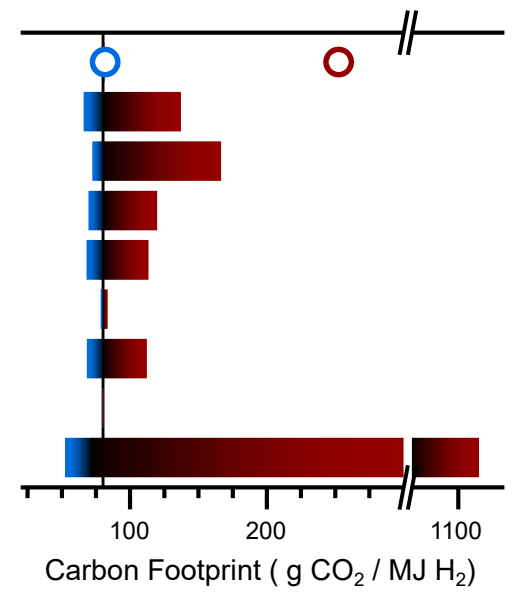

c

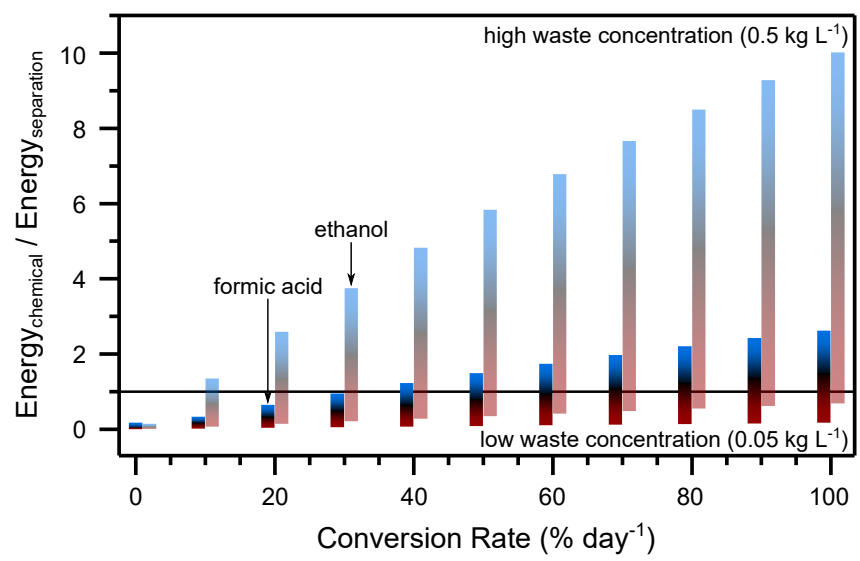

d

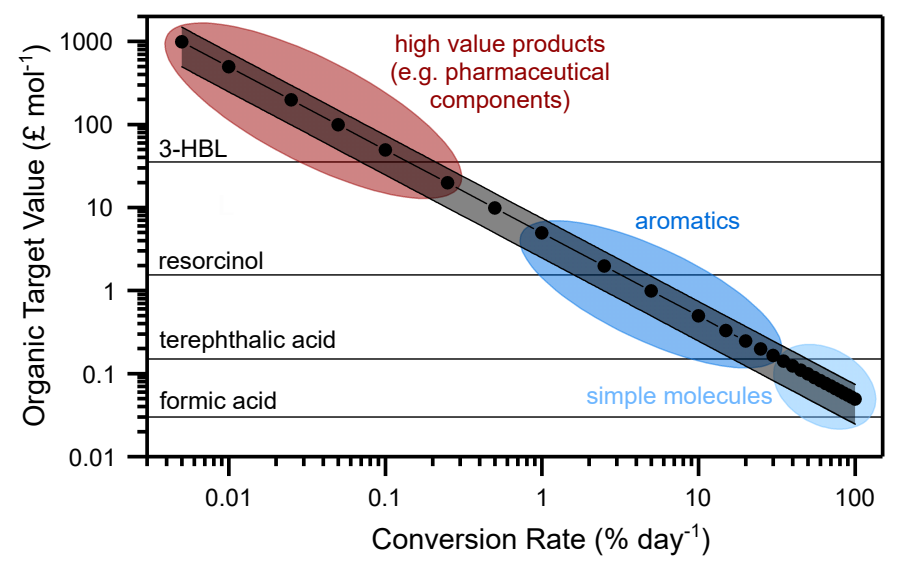


